\title{
Care in pediatric nursing from the perspective of emotions: from Nightingale to the present
}

\author{
O cuidar em enfermagem pediátrica na perspectiva das emoções: de Nightingale à atualidade
}

Atención de enfermería pediátrica desde la perspectiva de las emociones: del Nightingale hasta el presente

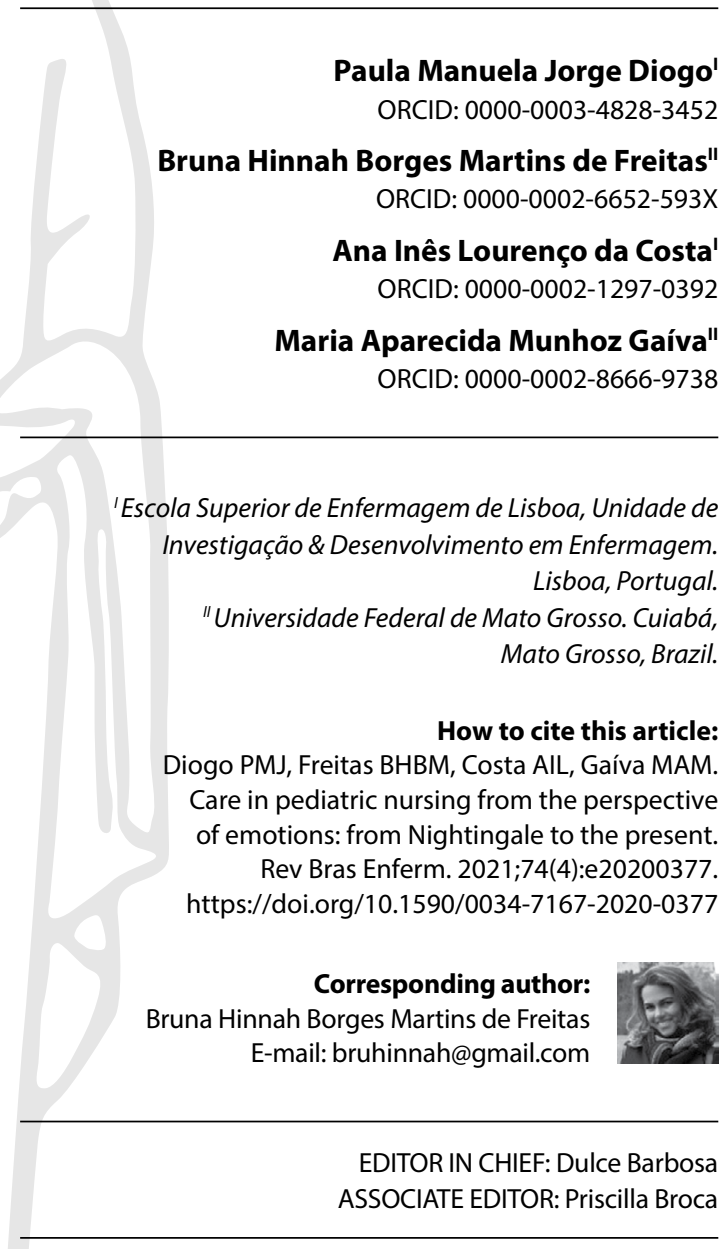

Submission: $04-28-2020$

Approval: $09-20-2020$

\section{ABSTRACT}

Objective: Reflect on the evolution of pediatric nursing care from the perspective of emotions, from the conceptions of Florence Nightingale to the present. Method: Reflective study based on theoretical and experiential aspects of emotional care in pediatric nursing. Results: From Nightingale, there were many definitions regarding the nursing care in an integrative and humanist logic; and with certain bond to emotional dimension. That time, nursing care was based on the religious conceptions of charity and love of our neighbor and, despite the conceptualization that shapes nursing science today, such conceptions have not ceased to be its attribute, mainly in the care of pediatric nurses. Final considerations: In pediatric nursing, nurture care with affection and facilitate emotions management in each interaction nurse-child-family is crucial for caring. This emotional care should evolve into a competence that recognizes the expertise and merit of professional action.

Descriptors: History of Nursing; Nursing Care; Pediatric Nursing; Emotions; Professional Competence.

\section{RESUMO}

Objetivo: Refletir sobre a evolução do cuidar em enfermagem pediátrica na perspectiva das emoções, desde as concepções de Florence Nightingale até a atualidade. Método: Estudo reflexivo fundamentado em aspectos teóricos e experienciais do cuidado emocional em enfermagem pediátrica. Resultados: Desde Nightingale, muitas foram as definições sobre o cuidar em enfermagem numa lógica integradora e humanista; e com alguma ligação à dimensão emocional. Naquele tempo, o cuidado de enfermagem se assentava nas concepções religiosas de caridade e amor ao próximo e, apesar da conceituação que molda a ciência de enfermagem na atualidade, tais concepções não deixaram de ser seu atributo, principalmente na assistência dos enfermeiros pediatras. Considerações finais: Em enfermagem pediátrica, nutrir os cuidados com afeto e facilitar a gestão das emoções em cada interação enfermeirocriança-família é crucial para o cuidar. Esse cuidado emocional deverá evoluir para uma competência, que reconheça a perícia e o mérito do agir profissional.

Descritores: História da Enfermagem; Cuidados de Enfermagem; Enfermagem Pediátrica; Emoções; Competência Profissional.

\section{RESUMEN}

Objetivo: Reflejar sobre la evolución del cuidar en enfermería pediátrica en la perspectiva de las emociones, desde las concepciones de Florence Nightingale hasta la actualidad. Método: Estudio reflexivo fundamentado en aspectos teóricos y experiencias del cuidado emocional en enfermería pediátrica. Resultados: Desde Nightingale, muchas son las definiciones sobre el cuidar en enfermería en una lógica integradora y humanista; y con alguna relación a la dimensión emocional. El cuidado de enfermería se basaba en concepciones religiosas y amor al próximo y, aunque la conceptuación que molda la ciencia de enfermería en la actualidad, tales concepciones no dejaron de ser su atributo, principalmente en la asistencia de enfermeros pediatras. Consideraciones finales: En enfermería pediátrica, nutrir los cuidados con afecto y facilitar la gestión de emociones en cada interacción enfermero-niño-familia es crucial para el cuidar. Ese cuidado deberá evolucionar para una competencia, que reconozca la pericia y el mérito del actuar profesional.

Descriptores: Historia de la Enfermería; Cuidados de Enfermería; Enfermería Pediátrica; Emociones; Competencia Profesional. 


\section{INTRODUCTION}

The history of nursing is continually under research and has been concentrated mainly on major events and processes related to the professionalization, and little to nursing praxis. However, the theorization that supports praxis and started with the promotion of Florence Nightingale's book, "Notes on Nursing", as a historic milestone, was developed around complex, transversal and tangential concepts such as caution and care, which were expressed, experienced and communicated in different ways over the time ${ }^{(1)}$.

For decades, nursing care was associated to religious practices of charity, love to the neighbor and donation. However, with the evolution of nursing as a science, new conceptions about nursing care were unveiled and worked under multiple perspectives and interfaces with physical, social, cultural, technical, spiritual, economic, and emotional dimensions. These advances have resulted in the improvement of nursing knowledge and praxis.

From Nightingale, pediatric nursing care has been made more flexible and individualized

according to the needs of each child and family. It should be understood as a relational process that generates a big emotional involvement. Many times, in the act of caring, it is needed to guarantee emotional, support, tranquility, tenderness, kindness, friendliness, good humor and patience ${ }^{(2)}$.

In this context, it is up to the nurse to act from the perspective of the emotions, since intense emotionality and suffering are inherent to the health-disease process, just as such perspective is required in the experience of caring. Thus, emotional care in pediatrics occurs when there is therapeutic intentionality in the gift of affection in caring for and in managing clients' emotions, promoting a safe and affectionate environment, as well as stability in therapeutic relationship. The latter is only possible when you are emotionally available to care $^{(3)}$.

Given these considerations, it is necessary a reflection regarding the evolution of pediatric nursing care from the perspective of emotions, from the pioneering conceptions of Florence Nightingale up to the present to better understand the link between caring and emotional dimension in nursing, aiming the best practices in health care for children and their families.

\section{OBJECTIVE}

Reflect on the evolution of pediatric nursing care from the perspective of emotions, from the conceptions of Florence Nightingale to the present.

\section{METHODS}

This is about a reflective study based on theoretical and experiential aspects of emotional care in pediatric nursing, organized in five parts: Caring in nursing: from Florence to the present; Caring in pediatric nursing; Emotional care in pediatric nursing; Emotional competence from pediatric nurses: conceptual aspects; and emotional labor as a therapeutic intervention in pediatric nursing: description of a caring experience.

\section{NURSING CARE: FROM FLORENCE TO THE PRESENT}

Although publications about the history of nursing are scarce, Florence Nightingale is the most notable in the registers, considered the pioneer of modern nursing and the first to design the nursing role. She gained greater prominence from her performance in the Crimean War, in which many soldiers died of unrestrained infection. Then, Nightingale noticed that the environment was connected to the health of the individuals and proposed policies that supported health and protocols at that time, resulting in better sanitary conditions and reducing the mortality of soldiers. After the war, her writings were fundamental in clarifying the standards of nursing conduct and strongly influenced this area as a profession ${ }^{(1)}$.

Therefore, she founded the conceptual and scientific bases of nursing, establishing guidelines and standards for teaching and practicing the profession. Nightingale explained holistic nursing based on the requirements of clients, families, communities and nations, considering simple elements, but with high efficiency, such as hygiene, feeding, organization of care, and respect. Based on the comprehension of this complexity, she extensively wrote on the myriad of social and environmental factors that influence people's well-being and health. Today, these factors are called "health determinants". In addition, she was the first research nurse in the world and instituted the first practices based in nursing evidences, which institutionalized the profession ${ }^{(1)}$.

At that time, nursing care was based in the religious conceptions of charity and love to the neighbor. Nightingale's path in nursing was guided by her spiritualist beliefs, characterized by her anxieties in the face of the suffering of their fellows ${ }^{(1)}$.

After her contributions, several nursing theories were instituted, and some converge to the humanistic care proposed by her, such as those that were compared by Piccoli and collaborators in summary tables in a recently published reflection article (4). For example, we have the humanistic theory of Paterson and Zderad (1976), which conceptualized nursing care as a vivid and dialogued meeting between client and nurse, which aims to promote the well-being and quality of life to subjects when sharing knowledge. In addition, in 1987, theoretical Parse (ManLife-Health Theory) attributed the conception that nursing care should allow human beings to make the decision about their health process, considering the intersubjectivity of people and families ${ }^{(4)}$

Recently, in 2010, in her theory of transitions ${ }^{(4)}$, Meleis considered nursing care as a nurses' action nucleus, which aims at emotional and relational well-being, and dominance. In 2012, with the theory of transpersonal care, Watson advocates that caring helps the person to reach the control, become flexible and promote modifications in the health based on the humanistic system of values that provides autonomy, freedom of choice, with emphasis on self-knowledge and self-control. For Watson, caring for human-to-human must be the axis of nursing practice ${ }^{(5)}$. Both theories share the interaction conviction between parties, emphasizing the person, environment, health, and nursing care - the four metaparadigmatic concepts of nursing today ${ }^{(4)}$. 
Something common among the four theories above mentioned is that they all reveal the perception that nursing care overcome the technical act, as it is subject to the interpersonal relationship between the nurse and the client, whose central elements are the subjectivity of the individuals involved ${ }^{(4)}$ and the human experiences of emotions ${ }^{(3)}$. In this sense, we can say that only the complete care in all its complexity, which includes the emotional experience of the individual who is cared for and the one who cares, can break with the Cartesian model of "treating" still in force in health.

\section{PEDIATRIC NURSING CARE}

Under an integrating prism, it is indispensable a curative, preventive and promotional health actions in childcare in the family, community and hospital contexts. The nurse should offer an integrating care in order to ensure that the child reaches his highest potential of growing and development. Monitoring child health by nurses associate several elements such as the ponderoestatural growth, neuropsychomotor development, immunization, breastfeeding, nutritional status, oral health, mental health, accident and violence prevention, early detection and timely treatment of prevalent childhood diseases, as well as other health problems.

In addition, this professional should detect risk factors and child protection for a better care planning. In such process, it is needed to consider the subjectivity of the individuals to ensure

practical success in childcare, besides the technical achievement. In this sense, the research that described the perception of hospitalized school-aged children regarding nursing care showed the emphasis given by them to the importance of these being carried out with kindness, affection and respect. It emphasizes that nurses should explain the procedures to them to understand its use and feel safe. Furthermore, they consider cordiality something essential for them to feel comfortable in the caring environment. They mention that, sometimes, procedures lead to pain, which requires more attention and kindness provided by the professional ${ }^{(6)}$.

Even during the hospitalization, childcare needs to consider several aspects that interfere in the health-disease process, aiming a more holistic approach, envisioned from Nightingale. From this perspective, well-being is achievable through the balance of biological, psychological, sociocultural, spiritual, developmental, and emotional systems ${ }^{(3)}$. Still, all this childcare process consists of a communicative act with the child and his family, which includes emotions, especially during sickness and hospitalization that requires more intensive care. In this scenario, you daily live with emotions like loss, fear and suffering. Because of that, it is needed to learn how to express emotions and feelings, both from those that are being cared and those that care ${ }^{(3)}$.

Furthermore, the environment needs to be the focus of nursing intervention because when it is the health promoter, it provides emotional stability and cooperates, so that the child reaches his maximum growth and development potential. Pediatric care should take into consideration the promotion of child's growth and development process ${ }^{(7)}$ and, in case of illness, the support should be given to the health transition process. This double challenge encompasses intense emotional experiences, requiring that the professional explore the relational and affective tendency in pediatric care.

Pediatric nurse needs humanization and non-traumatic care strategies, providing a safe and affective environment, controlling the emotions and building an auxiliary, empathetic and safe relationship ${ }^{(3)}$. Playing and jokes emerge as resources capable to minimize the anxiety and the fear at these moments. In order to get practical success in pediatrics, nursing professionals need to be funny and play, which reveals the need to include playful activities during the assistance ${ }^{(6)}$. It is also vital to include the family, allowing its presence and its active involvement, giving them the chance to provide emotional support and safe to the child in the whole caring process. In this, partnership is essential for the global development of the child as well as for the caring itself.

\section{EMOTIONAL CARE IN PEDIATRIC NURSING}

In nursing practice in a pediatrics contexts, emotions are essential once they give sense to the nurse intervention and to the caring itself, filling out the gaps of "technical care", guiding the relationship between the child and the family cared, and the nurse who takes cares ${ }^{(3)}$.

The concept of affection is directly related to the term "love", as both refer to a feeling present in nursing care. Pediatric nurses are aware and sensitive to nurture and enrich the caring directed to the child and the family with affection, expressing it in every action and/or interaction with the pediatric clients and helping them to manage their emotions. Therefore, affection is present in all nursing care relationships, with the gift of affection standing out as a component of the subjective dimension of emotional labor. The nurse should understand the child and the family as unique beings, catch their feelings, emotions and identify them, recognizing their singularity and totality; he/she should attribute meaning to the therapeutic intentionality of affection in caring, which is fundamental for emotional care in pediatrics ${ }^{(3)}$, whose objective is to provide harmony and well-being to the pediatric.

Therefore, nursing care, for involving a relational process, requires an understanding of the human experience of emotions in the care of the child and the family, an understanding that transcends material reality and values empathy and attention to the other. In this process "small things" or "caring gestures" are present, hard to catch, easy to escape, and little valued in the context of the bustle of nursing daily care ${ }^{(2)}$. In fact, these "small things" - singular and unique - are crucial for well-being of the child and the family took care by the nurse. Corroborating this idea, Watson ${ }^{(5)}$ calls the attention to the importance of the relation nurse-client that transcends the physical and material world, valuing the mind and the emotions as windows to the individual's soul.

Thus, nursing as a science of care cannot remain indifferent to human emotions ${ }^{(5)}$, since the pediatric relation nurse-client indicates the comprehension of human experience of emotions, its sharing, and an adaptive emotional management that reflects the emotional care. The emotional dimension of care is multifaceted and crucial for the practice, in which the therapeutic relation between nurse and pediatric client is valued, fundamental for 
the expression and sharing of emotions. The management of the flow of emotions of the parties involved in the relationship is, therefore, intrinsic to the process of caring ${ }^{(3)}$.

\section{EMOTIONAL COMPETENCE OF PEDIATRIC NURSES: CON- CEPTUAL ASPECTS}

Considering emotional care in pediatric nursing and its importance for the provision of quality and personalized care to the child and family, it is crucial to understand how it can be defined and characterized, in order to acquire it as a competence. The concept of emotional competence is still under construction and it still needs to be more explored and investigated, and over all, valued in nursing care practice, since it is crucial for the well-being of the clients as well as of the nurses, including their professional satisfaction. It is about highlighting emotional competence as a primary requirement for the daily performance of nurses in the context of pediatric care.

Thus, it is inferred that emotional competence requires education and training of nurses ${ }^{(2)}$; it is an essential part of humanized care and requires the nurse's emotional involvement in the therapeutic relationship. The emotional competence can create effective and welcoming environments for the child and family; facilitate the management of the emotions of the pediatric client for expressing the feeling processes, in addition to include personal skills to deal with the emotional world in an adaptive way; deal with the own emotions and relationships. These characteristics make possible the emotional involvement with the pediatric client and minimize the stress and burnout of the nurses ${ }^{(3)}$.

This way, it is important to present some educational strategies for the development of emotional competence and performance of emotional labor of pediatric nurses, such as the analysis of practices in the workplace with experienced nurses, emotional competence training focused on the client and family, training focused on the self-knowledge of emotions and on the reflective learning, and group dynamics techniques with emotional management exercises (3). Furthermore, health and teaching institutions can also promote scientific boards in order to discuss the meaning of the emotions in a healthcare context, as well as the development of expressiveprojective activities or workshops regarding the nursing emotional labor and the building/consolidation activities of the team.

\section{EMOTIONAL LABOR AS A THERAPEUTIC INTERVENTION IN PEDIATRIC NURSING: DESCRIPTION OF A CARING EX- PERIENCE}

Nursing emotional labor gained visibility from the pioneer investigation of Pam Smith ${ }^{(2)}$, who expanded the original concept of Sociology and applied it to nursing. The author highlights that the emotional labor is defined by the competences involved in caring and recognizing the emotions of others, and not only by the emotions experienced by nurses. In this sense, Diogo ${ }^{(3,8)}$ presents the Emotional Labor Model in Pediatric Nursing; in this model, it is highlighted the importance of nurses' emotional regulation in order to be emotionally available to nurture care with affection, through which the stability of relationships is built, promoting a safe and kindness environment, positively conditioning the management of emotional state of the children and their families.
Next, we present a description of the care experience that highlights the interaction between the nurse, a child and his family, in order to show the applicability of the Emotional Labor Model in Pediatrics Nursing ${ }^{(8)}$ :

John (fictitious name), 5 years old, and his mother went to a childcare consultation, and the nurse greets the mother and child, calling them by their names and greeting them with kisses and hugs. She greets John in a special way, bending to his level, squatting, looking him in the eyes and highlighting the beautiful clothes and how much he has grown since the last time they saw each other. In the consultation room, he asks his mother to sit down, and he also sits down, forming a triangular layout, and the nurse gives John freedom to play, asking him to tell her news while he plays. The nurse is wearing a colorful smock with dolls printed on it and uses it asking the child to look for the lion or the red bee. In the first part of the nursing consultation it is presented doubts, fears and concerns of John and his mother. During the consultation, the mother participates in undressing her son, weighing him, measuring him, calming him with her voice, her touch, and using distraction strategies (music and movies on her cell phone). The nurse, with her smile, joy, affectionate gestures, soft touches, a lulled voice and a gentle look, values the developmental milestones present, such as one-legged race, counting the number of jumps, kicking a ball, painting the figure among others [...] It follows with the vaccines, which take place in the vaccination room. The preparation for the vaccination carried out by the nurse for John and the mother is done with appropriate language, staying at eye level, squatting and using the book "I don't want to go to the vaccine", which the mother reads to her son. Then the nurse explains the procedure using the therapeutic toy technique. After consent, the nurse lets John to choose which arm he wants to receive the vaccine in (left or right) and also asks him for help in holding the adhesive bandage. The nurse explains in detail the procedure for administering the vaccine and often says "we are almost done". During vaccination, the mother is encouraged to give kisses, to hug her son, to hold him, to give affection, to hold hands. The nurse tickles and uses the bee's story [...] by the end of the consultation, she says goodbye to John and his mother with kisses and hugs, and the boy takes a sticker and his favorite drawing to paint. The nurse advises that, in case of any doubt or concern, they can call the unit and speak to her. Still, she highlights the importance of the nursing team for his emotional regulation, due to the calm environment and the possibility of sharing situations of care experienced of intense emotionality - for example, performing painful procedures for children and families.

This model was applied in different care contexts of pediatric and neonatal nursing. Researchers ${ }^{(9)}$ validated the content of this model with nurses of a neonatology unit, and $93 \%$ of the characteristics of the five intervention categories were considered as "Important", "Very Important", or "Essential" by them in its praxis. The model was also used by nurses that worked in pediatric labs at hospitals, being recognized as a practice guide in nursing consultation, as it based autonomous interventions in its five therapeutic categories/results ${ }^{(10)}$.

As you can see, the emotional labor has been developed in a promising way as an important intervention in caring, which is already being used by pediatric nurses in Portugal, but is still little known and discussed in the Brazilian situation. 


\section{FINAL CONSIDERATIONS}

It is considered that, from Nightingale, there were many conceptions regarding the nursing care, based on multiple views from theorists like Paterson and Zderad, Parse, Watson e Meleis. As much as there is a distinction between them, it is common for them to understand that nursing care transcends technical practices and procedures, as it depends on the interpersonal relationship established between the nurse and the client. They also argue that it is necessary to take care of the individual integrally.

Pediatric care includes the child and his family in promoting the child's growth and development process and, in case of illness, in the support that must be provided in the process of transition from illness to health. Challenges result intense emotional experiences both to the client and to the caregivers. Thus, nursing while a care science may not be indifferent to human emotions; there must be an understanding of the human experience of emotions, their sharing and adaptive emotional management, which characterizes emotional care.

For this reason, pediatric nurses need to have emotional skills and be sensitive to nurture affectionate and non-traumatic care, impressing it on every action and/or interaction with the child and family. This pediatric emotional labor assures consistency in the relation nurse-child-family, and promotes a safe, empathetic and affectionate environment, which positively preserves motional managements of the participants of this relationship. From this perspective, the Emotional Labor Model in pediatric nursing may be used to guide such practice, once it has been already applied in different care contexts of pediatric and neonatal nursing, showing satisfactory results in nursing praxis.

\section{ACKNOWLEDGEMENT}

I would like to thank the Dean of Research and the Dean of Graduate Studies at the Federal University of the State of Mato Grosso for supporting publication (Notice 01/2020).

\section{REFERENCES}

1. Dossey BM, Rosa WE, Beck D. Nursing and the sustainable development goals: from Nightingale to now. Am J Nurs. 2019;119(5):44-9. https://doi.org/10.1097/01.NAJ.0000557912.35398.8f

2. Smith P. Emotional labor of nursing revisited: can nurses still care? 2.a Edição. Hampshire: Palgrave Macmillan; 2012. 248 p.

3. Diogo PMJ. Trabalho com emoções em enfermagem pediátrica: um processo de metamorfose da experiência emocional no ato de cuidar. 2a Edição. Loures: Lusodidacta; 2015. 248 p.

4. Piccoli T, Nunes SFL, Tramontina PC, Oliveira RJT, Santos EKA, Amante LN. Reflecting on some nursing theories based on Meleis' Evaluation Model. Cogitare Enferm. 2015;20(2):433-8. https://doi.org/10.5380/ce.v20i2.37891

5. Watson J. Human caring science: a theory of nursing. 2nd Edition. London: Jones and Bartlett Learning, LLC; 2012.121 p.

6. Santos PM, Silva LF, Depianti JRB, Cursino EG, Ribeiro CA. Nursing care through the perception of hospitalized children. Rev Bras Enferm. 2016;69(4):646-53. https://doi.org/10.1590/0034-7167.2016690405i

7. Jones SM, Zaslow M, Darling-Churchill KE, Halle TG. Assessing early childhood social and emotional development: key conceptual and measurement issues. J Appl Dev Psychol. 2016;45:42-8. https://doi.org/10.1016/j.appdev.2016.02.008

8. Vilelas JMS, Diogo PMJ. Emotional labor in nursing praxis. Rev Gaúcha Enferm. 2014;35(3):145-9. https://doi. org/10.1590/1983-1447.2014.03.45784

9. Diogo PMJ, Martins H, Fernandes N. Aplicabilidade do Modelo de Trabalho Emocional em Enfermagem Pediátrica numa Unidade de Neonatologia. In: Sousa FGM, Rolim KMC, Fernandes HIVM, Figueiredo MCAB (Org.). Interfaces da Pesquisa no Cuidado de Enfermagem em Terapia Intensiva Neonatal e Pediátrica. Curitiba: Editora CRV; 2019. 53-86 p.

10. Figueiredo, AR. Aplicabilidade do Modelo de Trabalho Emocional em Enfermagem Pediátrica no Contexto de Consulta Externa de Pediatria. In: 2.as Jornadas Emoções em Saúde da UI\&DE/ESEL - Emoções, Afeto e Promoção da Saúde [Internet]. 2020 [cited 2020 Apr 20]. Available from: https://jornadasemocoesemsaude.home.blog/ aplicabilidade-do-modelo-do-trabalho-emocional-em-enfermagem-pediatrica-no-contexto-de-consulta-externa-de-pediatria/ 